\title{
Antimicrobial wound dressing films containing essential oils and oleoresins of pepper encapsulated in sodium alginate films
}

\section{Jessica Miranda Rosa ${ }^{1}$ Letícia Bicudo Bonato ${ }^{2}$ Carolina Bragine Mancuso $^{1}$ Laira Martinelli $^{1}$ Mônica Hitomi Okura ${ }^{2}$ Geoffroy Roger Pointer Malpass ${ }^{1,2}$ Ana Claudia Granato ${ }^{1,2^{*}}$}

${ }^{1}$ Departamento de Engenharia Química, Universidade Federal do Triângulo Mineiro (UFTM), 38064-200, Uberaba, MG, Brasil.

${ }^{2}$ Programa de Mestrado Profissional em Inovação Tecnológica (PMPIT), Universidade Federal do Triângulo Mineiro (UFTM), 38064-200, Uberaba, MG, Brasil. E-mail: ana.malpass@uftm.edu.br. "Corresponding author.

\begin{abstract}
Medicated wound dressings are important barriers to avoid contamination and, when they contain antimicrobial additives, can be used as treatment for infected wounds. There are several types of polysaccharide materials that serve as matrices for medicated wound dressings, among them, sodium alginate. For the preparation of the films studied in this paper, sodium alginate was employed in combination with essential oils/oleoresins (EO/OL) of six peppers that are commonly used in cooking. The EO/OL were incorporated at three different concentrations (low, intermediate and high). Most of the films prepared had better dispersion of the EO/OL at the intermediate concentration. All films studied in this research were dissolved in water at different rates. The antibacterial activity of the prepared films showed significant results against Escherichia coli, Staphylococcus aureus and Bacillus cereus, and demonstrated that the films studied may be a new alternative for medicated wound dressings.
\end{abstract}

Key words: medicated wound dressings, alginate-based films, essential oils, oleoresins, antibacterial activity.

Curativos medicamentosos antimicrobiano contendo óleos essenciais e oleoresinas de algumas pimentas encapsulados em filmes de alginato de sódio

RESUMO: Os curativos medicamentosos são importantes barreiras para se evitar contaminação e ainda, quando contém aditivos antimicrobianos, servem como tratamento para ferimentos infectados. Existem vários tipos de materiais polissacarídicos que servem como matrizes para curativos medicamentosos, dentre eles, destaca-se o alginato de sódio. Para a preparação dos filmes estudados neste trabalho, utilizou-se alginato de sódio e incorporou-se óleos essenciais/oleoresinas (OE/OL) de seis pimentas utilizadas na culinária, em três diferentes concentrações. A maioria dos filmes preparados apresentou melhor dispersão dos OE/OL na concentração intermediária destes. Todos os filmes estudados neste trabalho apresentam solubilidade em água, em uma certa extensão. A atividade antibacteriana dos filmes preparados mostra resultados significantes contra Escherichia coli, Staphylococcus aureus e Bacillus Cereus, mostrando que os filmes estudados podem ser uma nova alternativa como curativos medicamentos.

Palavras-chave: curativos medicamentosos, filmes de alginato, óleos essenciais, oleoresinas, pimentas, atividade antibacteriana.

\section{INTRODUCTION}

Any kind of wound dressing, surgical or not, provides a barrier from environmental contamination and reduces the risk of infection. In addition, the use of dressings can be more interesting when they have additional potential benefits - such as antimicrobial properties. Many types of dressing for wounds and burns are reported in the literature (MOGOSANU \& GRUMEZESCU, 2014). The most promising materials for wound/burn dressings are based on natural polysaccharides (such as alginates, among others), proteoglycans and proteins (Mogosanu \& Grumezescu, 2014).

Sodium alginate (NaAlg) is a linear unbranched natural polysaccharide which contains different amount of $\left(1 \rightarrow 4^{\prime}\right)$ - covalently linked $\beta$-D-mannuronate and $\alpha$-L-guluronate residues (MOGOSANU \& GRUMEZESCU, 2014; LIAKOS et al., 2014). Alginate is obtained from algae and its compounds (calcium alginate, calcium-sodium alginate, collagen-alginate or gelatin-alginate) form 
highly absorbent natural fibre dressings (THU et al., 2012; MOGOSANU \& GRUMEZESCU, 2014). Alginate is a biodegradable and biocompatible natural material that absorbs water and/or body fluids up to 20 times its own weight (GARDNER, 2004; LIAKOS et al., 2014). This hydrophilic gel provides a moist wound-healing environment. However, as alginate dressings have no adhesive properties, it is necessary to use a secondary dressing in order to protect and fix the alginate film (VIJAYARAAGHAVAN \& GOPALAKRISHNAN, 2005; LEE et al., 2007B; GOH et al., 2012; MOGOSANU \& GRUMEZESCU, 2014).

In moist conditions alginate has the ability to swell, releasing encapsulated bioactive compounds (SACHAN et al., 2009; LIAKOS et al., 2014). NaAlg is also preferred as a matrix material for wound dressing applications as it has been shown to have wound healing properties (KIM et al., 2008; DANTAS et al., 2011; LIAKOS et al., 2014). The literature reports that alginates can activate human macrophages and generate a proinflammatory signal that may initiate a resolving inflammation characteristic of healing wounds (THOMAS et al., 2000).

Although, NaAlg does not present antimicrobial properties, which would be important for a wound dressing, then bioactive additives can be added to the films to make then functional films. Among many studied additives, essential oils have been successfully added to biofilms to impart antimicrobial activity (BENAVIDES et al., 2012; ANGHEL et al., 2012; GRUMEZESCU et al., 2012; CHARERNSRIWILAIWAT et al., 2013; LIAKOS et al., 2014; LIAKOS et al., 2015).

Among natural antimicrobial substances, essential oils have been widely studied. Essential oils (EO) are natural products from the secondary metabolism of plants and present a broad spectrum of action, including antioxidant activity (BEN et al., 2009; GONI et al., 2009; WENQIANG et al., 2007), antifungal activity (BEN et al., 2009; GONI et al., 2009; GACHKAR et al., 2007; SOUZA et al., 2007) and antibacterial activity (BEN et al., 2009; GONI et al., 2009). Despite the fact that the antimicrobial mechanism of action of EOs is not completely understood, it is believed that the activity is due to their hydrophobicity (SÁNCHEZGONZÁLEZ et al., 2011). The main objective of this article was to prepare alginate wound dressing films encapsulated with essential oils/oleoresins obtained from peppers.

\section{MATERIALS AND METHODS}

\section{Materials}

Sodium Alginate salt with viscosity $15.000-20.000 \mathrm{cps}$, Glycerol $\geq 99.5$ (density $=1.261 \mathrm{~g}$ ) $\mathrm{cm}^{3}$ ) and Igepal CO-520 (Polyoxyethylene (5) nonylphenylether; density $\approx 1 \mathrm{~g} / \mathrm{cm}^{3}$ ) were purchased from Sigma-Aldrich. The dye Chamomile blue was obtained commercially (Ferquimia). The essential oils (EO) of Schinus terebinthifolius, Pimenta dioica and Piper nigrum (white) and the oleoresins (OL) of Piper nigrum (white), Piper nigrum (black) and Capsicum baccatum were extracted using Clevenger and Soxhlet methods, respectively, according to MARTINELLI et al. (2017).

The test microorganisms used to determine the antimicrobial activity of the prepared films were: Gram-negative bacteria: Escherichia coli (ATCC 35218), Gram-positive bacteria: Staphylococcus aureus (ATCC 29213) and Bacillus cereus (ATCC 11778). PCA medium agar was purchased from Merck.

\section{Preparation of the films}

The films were prepared according to the methodology presented by LIAKOS et al. (2014): A sample of $10 \mathrm{ml}$ of distilled water and $0.3 \mathrm{~g}$ of NaAlg were mixed and heated for $1 \mathrm{~h}$ at $\sim 100^{\circ} \mathrm{C}$. After the viscous solution cooled to room temperature, $0.1 \mathrm{ml}$ of glycerol, different volumes $(0.1,0.5$ and $1.0 \mathrm{ml})$ of essential oils/oleoresins and $100 \mu \mathrm{L}$ of Igepal were slowly added to the $\mathrm{NaAlg} /$ glycerol solutions. The final solutions (total volume $=10 \mathrm{~mL}$ ) were mixed using a vortex mixer. To the final solution $(200 \mu \mathrm{L}$ of each) it was added dropwise on to glass slides of $1.5 \mathrm{~cm}^{2}$ and left to dry under ambient laboratory conditions. As with the methodology of LIAKOS et al. (2014) three different films for each essential oil/oleoresin were casted with each containing three different essential oil/oleoresin concentrations (w/w) based on dry film weight percentage: low EO/OL-concentration (16\%), intermediate EO/OL-concentration (50\%) and high EO/OL-concentration (66\%).

\section{Surface films analysis}

The surface films analysis were conducted with a Digital Optical Microcopy Leica (Model MZ8, Leica AG, Heerbrugg, Suíça) coupled to a computer and camera.

Stability/decomposition of NaAlg/EOs films in water The stability/decomposition of the films were studied employing the methodology 
of LIAKOS et al. (2014). The experiments were carried out using chamomile blue essential oil due to its distinct blue colour. Films tested were NaAlg/ glycerol/chamomile blue blend, NaAlg/glycerol/ Igepal/chamomile blue blend and $\mathrm{NaAlg} /$ glycerol/ Igepal/EO-Intermediate concentration/chamomile blue blend. After drying, the free standing films were removed from the glass and placed inside Petri dishes filled with $10 \mathrm{ml}$ of water. Then, the dissolution of the samples in different time intervals.

\section{Antibacterial activity of NaAlg-EOs films}

In these experiments the activity of $\mathrm{NaAlg} / \mathrm{EOs}$ films deposited on glass slides was tested against three different microorganisms: a Gram-negative bacteria E. coli, and two Grampositive bacteria $S$. aureus and $B$. cereus that are agents of many opportunistic infections in humans. To assess the antibacterial behaviour of NaAlg/ EOs films, the bacterial cultures were diluted to a final concentration of $10^{6}$ cells $/ \mathrm{ml}$ and $500 \mu \mathrm{L}$ of this solution was spread onto new PCA medium agar plates. Plates were then placed in the incubator at $37^{\circ} \mathrm{C}$ for $2 \mathrm{~h}$. Films were casted from $200 \mu$ l solutions on $1.5 \mathrm{~cm}^{2}$ glass slides.

\section{RESULTS AND DISCUSSION}

\section{Surface films analysis}

The EO antimicrobial mechanisms of action is reported to be based on their hydrophobic nature (SÁNCHEZ-GONZÁLEZ et al., 2011). However, according to LIAKOS et al. (2014), EOs can cause a decrease in the interactions with $\mathrm{NaAlg}$ hydrophilic phase causing a poor dispersion of these in the matrix. However, when a surfactant is added to the film, it is possible to verify a much better dispersion of EOs in the NaAlg matrices by the increase of the EO miscibility in the NaAlg matrix and a reduction in the size of the EO domain.

From the micrography analysis it was possible to verify the film with Igepal has a better dispersion of the matrix when compared with the film without Igepal. It was also possible to verify that the EO is effectively dispersed within the $\mathrm{NaAlg}$ matrix film at all the concentrations, although, the intermediate concentration shows the best dispersion of the $\mathrm{EO}$ within the matrix.

\section{Antibacterial activity of NaAlg-EOs films}

Table 1 summarizes results of inhibition zones of all the functional films prepared in this study. According to these results, all the films were able to inhibit the growth of all microorganisms tested in three $\mathrm{EO} / \mathrm{OL}$ concentrations tested. However, it is curious that in almost all cases the increase in the concentration does not lead to an associated increase in the antibacterial activity. In fact, $15.90 \%$ of the samples tested had the best result in the lowest EO/OL concentration, $11.11 \%$ in the intermediate $\mathrm{EO} / \mathrm{OL}$ concentration and $4.70 \%$ in the highest $\mathrm{EO} / \mathrm{OL}$ concentration.

The film with all the concentrations of $S$. terebinthifolius EO resulted in the best result of antibacterial activity for $B$. cereus. However, the film with lowest concentration of $P$. dioica EO also showed a reasonable activity and the best result for B. cereus.

Examining the E. coli, the film with highest concentration of $P$. nigrum (white) EO had the best result. Although,films with the intermediate concentration of C. baccatum OL and $S$. terebinthifolius $\mathrm{EO}$ also provide comparable results of antibacterial activity for this microorganism.

Taking into account $S$. aureus, the best results were the films with lowest concentration of P. nigrum (white) EO and intermediate concentration of $S$. terebinthifolius EO. In general, the films with $S$. terebinthifolius, $P$. nigrum (white) and $P$. dioica EO presented the highest inhibition zones of all the films studied. These results agree with MARTINELI et al. (2017) were the authors also obtained promising results for the essential oils/ oleoresins of these peppers.

The antibacterial activities of the films were monitored over 30 days, testing the antibacterial activity every 3 days. Films were prepared and kept at $3^{\circ} \mathrm{C}$ in hermetically closed transparent and atoxic plastic bags. The antibacterial activity of all the films studied maintained their activity over the studied period, having no decrease in antibacterial activity, i.e., the inhibition zones were the same for the entire period. These results suggested that these films may be used as wound dressing for infected wounds, not just because of their antibacterial activity, but also for the proved healing properties of sodium alginate, as suggested by KIM et al., 2008, DANTAS et al., 2011, LIAKOS et al., 2014.

Stability/decomposition of NaAlg/EOs films in water A small piece $(2 \times 2 \mathrm{~cm})$ of the intermediate EO/OL concentration were used for this study. Samples were deposited in Petri dishes with $10 \mathrm{ml}$ of water as described by LIAKOS et al. (2014). The film dissolution was rapid and in 10min all films studied were completely dissolved as described by LIAKOS et al. (2014). In a highly moist environment the films start to release the $\mathrm{EO} / \mathrm{OL}$ due to the humidity 
Table 1 - Results of inhibition zone of the antimicrobial activity performed with the films.

\begin{tabular}{|c|c|c|c|c|}
\hline Essential Oil (EO)/Oleoresin (O) & $\%$ & B. cereus & E. coli & $S$ aureus \\
\hline \multirow[t]{2}{*}{ Alginat-based film } & 0 & 0 & 0 & 0 \\
\hline & 16 & 48.2 & 32.0 & 34.0 \\
\hline \multirow[t]{3}{*}{ EO $P$. dioica } & 50 & 38.5 & 36.7 & 31.0 \\
\hline & 66 & 44.5 & 33.5 & 27.0 \\
\hline & 16 & 36.5 & 40.0 & 50.0 \\
\hline \multirow[t]{3}{*}{ EO P. nigrum (white) } & 50 & 33.0 & 35.0 & 36.2 \\
\hline & 66 & 30.5 & 43.0 & 47.0 \\
\hline & 16 & All zone & 36.7 & 36.5 \\
\hline \multirow[t]{3}{*}{ EO S. terebinthifolius } & 50 & All zone & 39.2 & 49.2 \\
\hline & 66 & All zone & 33.2 & 33.0 \\
\hline & 16 & 38.5 & 37.5 & 42.5 \\
\hline \multirow[t]{3}{*}{ O C. baccatum } & 50 & 42.7 & 40.0 & 45.2 \\
\hline & 66 & 34.2 & 36.7 & 35.0 \\
\hline & 16 & 25.7 & 35,7 & 31.5 \\
\hline \multirow[t]{3}{*}{ O P. nigrum (black) } & 50 & 35.2 & 33.0 & 24.2 \\
\hline & 66 & 34.5 & 32.0 & 21.2 \\
\hline & 16 & 25.5 & 31.0 & 41.5 \\
\hline \multirow[t]{3}{*}{ O P. nigrum (white) } & 50 & 22.5 & 30.5 & 46.7 \\
\hline & 66 & 23.5 & 31.0 & 27.7 \\
\hline & 16 & 35.7 & 37.2 & 32.0 \\
\hline \multirow[t]{2}{*}{ O S. terebinthifolius } & 50 & 22.2 & 22.7 & 21.7 \\
\hline & 66 & 23.0 & 19.7 & 41.0 \\
\hline
\end{tabular}

adsorption by the matrix, as described by LIAKOS et al. (2014). It is an important property once the film can be removed from the patient washing with water, leading no residues.

\section{CONCLUSION}

In the present study it was possible to verify that alginate based films containing pepper essential oils/oleoresins present significant antibacterial activity against E. coli, $S$. aureus and B. cereus, important microorganism that can cause human infection. The films studied presented adequate dispersion of the essential oils/oleoresins at the surface matrix, which is a good characteristic, once it shows the same amount of the antimicrobial compounds will be released from all the points of the surface. Water solubility demonstrated that all of the films solubilize to some extent in water and that films can be removed from the patient skin, for example, washing with water. Results obtained indicated that alginate-based films encapsulated with peppers essential oils/oleoresins may be used as antibacterial wound dressings to treat human and animal's infected wounds.

\section{ACKNOWLEDGEMENTS}

The authors acknowledge the financial support of Fundação de Amparo à Pesquisa do Estado de Minas Gerais (FAPEMIG) and Conselho Nacional de Desenvolvimento Científico e Tecnológico (CNPq).

\section{CONFLICT OF INTEREST}

There is no conflict of interest.

\section{REFERENCES}

ANGHEL, I. et al. Modified wound dressing with phytonanostructured coating to prevent staphylococcal and pseudomonal biofilm development. Nanoscale Research Letter, V.7, p.1-8, 2012. Available from: <https://nanoscalereslett. springeropen.com/articles/10.1186/1556-276X-7-690>. Accessed: Jan. 05, 2018. doi: 10.1186/1556-276X-7-690.

BEN Taarit M. et al. Plant growth, essential oil yield and composition of sage (Salvia officinalis L.) fruits cultivated under salt stress conditions. Industrial Crop and Products, v.30, p.333-337, 2009. Available from: <https://www.sciencedirect. com/science/article/pii/S0926669009000867>. Accessed: Jan. 05, 2018. doi: 10.1016/j.indcrop.2009.06.001.

BENAVIDES, S. et al. Physical, mechanical and antibacterial properties of alginate film: Effect of the crosslinking degree 
and oregano essential oil concentration. Journal of Food Engineering, v.110, p.232-239, 2012. Available from: $<\mathrm{https} / /$ www.sciencedirect.com/science/article/pii/S0260877411002792>. Accessed: Jan. 05, 2018. doi: 10.1016/j.jfoodeng.2011.05.023.

CHARERNSRIWILAIWAT, N. et al. Electrospun chitosanbased nanofiber mats loaded with Garcinia mangostana extracts. International Journal of Pharmaceutics, v.452, p.333-343, 2013. Available from: <https://www.sciencedirect.com/science/ article/pii/S0378517313004110>. Accessed: Jan. 05, 2018. doi: 10.1016/j.ijpharm.2013.05.012.

DANTAS, M. D. M. et al. Improvement of dermal burn healing by combining sodium alginate/chitosan-based films and low level laser therapy. Journal Photochemistry and Photobiology B: Biology, v.105, p.51-59, 2011. Available from: <https://www.sciencedirect. com/science/article/pii/S1011134411001606>. Accessed: Jan. 05, 2018. doi: 10.1016/j.jphotobiol.2011.06.009.

GACHKAR, L. et al. Chemical and biological characteristics of Cuminum cyminum and Rosmarinus officinalis essential oils. Food Chemistry, v.102, p.898-904, 2007. Available from: <https:// www.sciencedirect.com/science/article/pii/S0308814606005061>. Accessed: Jan. 05, 2018. doi: 10.1016/j.foodchem.2006.06.035.

GARDNER, R. L. Application of alginate gels to the study of mammalian development. Methods in Molecular Biology, v.254, p.383-392, 2004. Available from: <https://www.ncbi.nlm.nih.gov/ pubmed/15041776>. Accessed: Jan. 05, 2018. doi: 10.1385/159259-741-6:383.

$\mathrm{GOH}, \mathrm{C}$. H. et al. Alginates as a useful natural polymer for microencapsulation and therapeutic applications. Carbohydrate Polymers, v.88, p.1-12, 2012. Available from: <https://www. sciencedirect.com/science/article/pii/S0144861711010046>. Accessed: Jan. 05, 2018. doi: 10.1016/j.carbpol.2011.11.012.

GONI, P. et al. Antimicrobial activity in the vapour phase of a combination of cinnamon and clove essential oils. Food Chemistry, v.116, p.982-989, 2009. Available from: <https:// www.sciencedirect.com/science/article/pii/S0308814609003689>. Accessed: Jan. 05, 2018. doi: 10.1016/j.foodchem.2009.03.058.

GRUMEZESCU, A.M. et al. Hybrid nanomaterial for stabilizing the antibiofilm activity of Eugenia carryophyllata essential oil. IEEE Transactions on Nanobioscience, v.11, p.360-365, 2012. Available from: <http://ieeexplore.ieee.org/document/6290401/>. Accessed: Jan. 05, 2018. doi: 10.1109/TNB.2012.2208474.

KIM, J.O. et al. Development of polyvinyl alcohol-sodium alginate gel-matrixbased wound dressing system containing nitrofurazone. International Journal of Pharmaceutics, v.359, p.79-86, 2008 Available from: <https://www.sciencedirect.com/science/article/ pii/S0378517308002184>. Accessed: Jan. 05, 2018. doi: 10.1016/j. ijpharm.2008.03.021.

LEE, M.S. et al. Preparation and characterization of small intestinal submucosa coated with alginate/gelatin as a wound dressing. Key Engineering Materials, v.342, p.69-72, 2007. Available from: <https://www.scientific.net/KEM.342-343.69>. Accessed: Jan. 05, 2018. doi: 10.4028/www.scientific.net/KEM.342-343.69.
LIAKOS, I. et al. Fibrous wound dressings encapsulating essential oils as natural antimicrobial agents. Journal of Materials Chemistry B, v.3, p.1583-1589, 2015. Available from: <http://pubs. rsc.org/-/content/articlelanding/2015/tb/c4tb01974a\#!divAbstract>. Accessed: Jan. 05, 2018. doi: 10.1039/C4TB01974A.

LIAKOS, I. et al. All-natural composite wound dressing films of essential oils encapsulated in sodium alginate with antimicrobial properties. International Journal of Pharmaceutics, v.463, p.137-145, 2014. Available from: <https://www.sciencedirect. com/science/article/pii/S0378517313009605>. Accessed: Jan. 05, 2018. doi: 10.1016/j.ijpharm.2013.10.046.

MARTINELLI, L. et al. Antimicrobial activity and chemical constituents of essential oils and oleoresins extracted from eight pepper species. Ciência Rural, v.47, n.5, p.1-7, 2017. Available from: $<$ http://www.scielo.br/pdf/cr/v47n5/1678-4596-cr-47-05-e20160899. pdf>. Accessed: Jan. 05, 2018. doi: 10.1590/0103-8478cr20160899.

MOGOSANU, G.D.; GRUMEZESCU, A.M., Natural and synthetic polymers for wounds and burns dressing. International Journal of Pharmaceutics, v.463, p.127- 136, 2014. Available from: <https://www.sciencedirect.com/science/article/pii/ S0378517313010831>. Accessed: Jan. 05, 2018. doi: 10.1016/j. ijpharm.2013.12.015.

SACHAN, N.K. et al. Sodium alginate: the wonder polymer for controlled drug delivery. Journal of Pharmacy Research, v.2, p.1191-1199, 2009. Available from: <http://jprsolutions. info/files/final-file-56b22486ed6434.87804114.pdf $>$. Accessed: Jan. 05, 2018.

SÁNCHEZ-GONZÁLEZ, L. et al. Use of Essential Oils in Bioactive Edible Coatings. Food Engineering Reviews, v.3, p.1-16, 2011. Available from: <https://link.springer.com/ article/10.1007/s12393-010-9031-3>. Accessed: Jan. 05, 2018.

SOUZA, E.L. et al. Effectiveness of Origanum vulgare L. essential oil to inhibit the growth of food spoiling yeasts. Food Control, v.18, n.5, p.409-413, 2007. Available from: <https://www.sciencedirect. com/science/article/pii/S0956713505002860>. Accessed: Jan. 05, 2018. doi: 10.1016/j.foodcont.2005.11.008.

THOMAS, A. et al. Alginates from wound dressings activate human macrophages to secrete tumour necrosis factor- $\alpha$. Biomaterials, v.21, p.1797-1802, 2000. Available from: <https://www.ncbi.nlm. nih.gov/pubmed/10905462>. Accessed: Jan. 05, 2018.

THU, H.E. et al. Alginate based bilayer hydrocolloid films as potential slow-release modern wound dressing. International Journal of Pharmaceutics, v.434, p.375-383, 2012. Available from: $<$ https://www.sciencedirect.com/science/article/pii/ S0378517312005443>. Accessed: Jan. 05, 2018. doi: 10.1016/j. ijpharm.2012.05.044.

WENQIANG, G. et al. Comparison of essential oils of clove buds extracted with supercritical carbon dioxide and other three traditional extraction methods. Food Chemistry, v.101, p.15581564, 2007. Available from: <https://www.sciencedirect.com/ science/article/pii/S0308814606003256>. Accessed: Jan. 05, 2018. doi: 10.1016/j.foodchem.2006.04.009. 